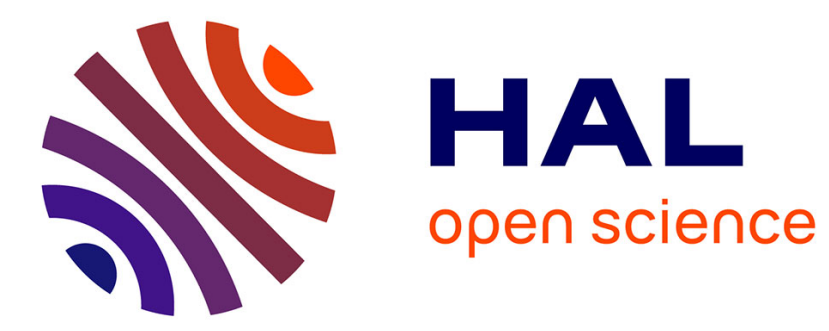

\title{
Territory beyond the anglophone tradition
}

\author{
Cristina del Biaggio
}

\section{To cite this version:}

Cristina del Biaggio. Territory beyond the anglophone tradition. John A. Agnew, Virginie Mamadouh, Anna Secor, Joanne Sharp. The Wiley Blackwell Companion to Political Geography, Wiley-Blackwell, pp.35-47, 2015, 9781118725887. hal-02568063

\section{HAL Id: hal-02568063 \\ https://hal.science/hal-02568063}

Submitted on 8 May 2020

HAL is a multi-disciplinary open access archive for the deposit and dissemination of scientific research documents, whether they are published or not. The documents may come from teaching and research institutions in France or abroad, or from public or private research centers.
L'archive ouverte pluridisciplinaire HAL, est destinée au dépôt et à la diffusion de documents scientifiques de niveau recherche, publiés ou non, émanant des établissements d'enseignement et de recherche français ou étrangers, des laboratoires publics ou privés. 
Title: "Territory beyond the Anglophone tradition"

Published in: John A. Agnew, Virginie Mamadouh, Anna Secor, Joanne Sharp (eds.), The Wiley Blackwell Companion to Political Geography, Wiley Blackwell, 2016: 35-47. http://eu.wiley.com/WileyCDA/WileyTitle/productCd-1118725883.html

\section{Author: Cristina Del Biaggio}

\section{Abstract}

The Francophone "territoire" is often translated by the English "place" and not by "territory", as the common sense would suggest. This detail underscores a deeper, and epistemological, difference existing between the Anglophone "territory" and the Francophone "territoire". The Francophone territoire never so strictly coincided with a bounded state territory, as in the Anglophone tradition. In the Francophone territoire the logics of agents and not necessarily state-agents, are included, and historically the concept of territoire allowed Francophone geography to become a social science in its own right. As such, territoire conceived in the Francophone way, is nowadays a powerful scholars tool to explore the contemporary world, made of a combination of borders, networks and overlapping territories. Despite the evident interest of conceiving territories beyond a state-centric view, Anglophone geographers, as opposed to their Francophone colleagues, never dare to do so. This chapter aims to present to an Anglophone audience how the Francophone tradition conceives territory and how it links it with issues of identities, projects and agents.

Keywords: territory; territoire; place; network; bounded space; region; agent; identity; appropriation; Alps; Alpine region. 


\section{Introduction}

"Territories still matter," even in a globalized world, affirms Antonsich $(2009,789)$. Paradoxically, territory has never been discussed as much as in the last decades, exactly when international relations seem less and less regulated by it (Badie 1996, 114). This is especially paradoxical if the term territory is considered to coincide with state territory, as is mostly the case in Anglo-Saxon geography. It is less paradoxical for Francophone geographers, because their conception of the territoire has never been so strictly linked with national boundaries as has that of Anglophone geography, in which, as suggested by Antonsich "territory, rather than being explored under the new conditions of globalization, has simply been discarded with the nation-state itself" (2009, 795). In fact, only a few scholars have written on territory in Anglophone geography, notably Soja (1971), Gottmann (1973) and Sack (1983) (see Dell'Agnese 2013; Elden 2010; Elden 2010a; Paasi 2003).

Territory, this "thing" that Cox considers the "central concept in political geography" (Cox 1991), is not quite the same for scholars writing in English or in French. And this statement goes beyond a simple lexical difference. It is not only that the Francophone "territoire" is often translated by the English "place" and not by "territory", as common sense would suggest. It is also because the difference is epistemological and as such this difference between territoire and territory opens the door to new research perspectives that will be partly uncovered with this article.

Francophone perspectives on the concept of territory have been and are broad. In fact, Klauser recalls in his introduction to the special issue of Environment and Planning $D$ paying tribute to Raffestin's conception of territoriality how Raffestin's work aimed to construct a theory of territoriality, which, he writes, is "ultimately a "theory of the real'" (Klauser 2012, 109-110). Raffestin's and other Francophone geographers' attempts to grasp the relation between human beings and the world through territory thus reflect a [p.35] broader conception of territory, compared to that of Anglophone scholars. The latter concentrated on mainly two ideas:

- The first is a "[reading] of territoriality [...] concerned, predominantly, with the study of geopolitical strategies of control/defence of space and with the resulting politicalterritorial arrangements" (Klauser 2012, 110). This leads Taylor to declare that "across the whole of our modern world, territory is directly linked to sovereignty to mould politics into a fundamentally state-centric social process" (Taylor 1994, 151, see as well Dell'Agnese 2013). A territorial state is a "simple" container of power, wealth, culture and society (Taylor 1994, 152; see as well Elden, 2010a, 757; Taylor 1995, 1);

- The second Anglophone notion of territory is an interpretation of territory as a transposition of ethological theories into social sciences, following Ardrey's book The Territorial Imperative (Ardrey 1966; see as well Murphy 2012, 159). This idea was notably brought into geography by scholars such as Soja (1971) and Gottmann (1973) (Murphy 2012: 159), but also by Sack, who, however, "treated human territoriality as fundamentally distinct from animal territoriality in that the former is not the product of instinct but is instead a culturally situated process intended to achieve particular political and social ends" (Murphy 2012: 160-161).

Yet, as Debarbieux $(1999,34)$ points out, in French as in English, territory has the same Latin etymology and the term had a similar evolution in the two contexts: it first took a juridicalpolitical meaning (the territory of the state) and then an ethological one (the area appropriated by an animal or a group of animals). It is only in the 1970s and 1980s that the meaning split. While Anglophone geographers did not detach territory from the state, Francophone geographers considered territoire to have multifaceted connotations. The Francophone tradition 
has thus been richer concerning territoire from the 1970s onward.

Anglo-Saxon scholars rediscovered only recently the relevance of territory, while the French territoire has been enriching research for more than 30 years. In order to uncover the "Francophone way" of understanding territory, I start by analyzing the Alpine regional construction's process. In this section, the relevance of territories is examined, introducing the (not necessarily) opposite notion of networks. Building from this concrete example, I discuss in which ways territories have to be considered as bounded, though not necessarily state-bounded, spaces. The third section discusses the suitability of considering the Francophone territoire equivalent to the Anglophone place. Both territoires and places are conceived as entities capable, especially due to the propensity of actors of building networks, of escaping the so-called "territorial trap" (Agnew 1994). However, if epistemologically place in English, had the same effect as territoire in French - that is, it helped to think spatial units beyond their jurisdictional meaning - place and territoire cannot be considered equivalent. Territoire has a longer history in the Francophone geography, though it has yet to come to fruition in the Anglophone study of territory. Thus, in the fifth section, the differences between the Francophone territoire and the English territory will be discussed, emphasizing the Francophone meaning. The sixth section exposes a sort of typology, proposed by Giraut (2008), in which territory is tied between two extremities: a specific notion, linked to the state, and a buzzword, linked to the social and cultural uses of space. This last conception will bring to the last section of the article in which it is shown how territoire allowed Francophone geography to become a social science and to left behind its state-centric conception. [p.36]

\section{The Alpine case study}

The social and political processes taking place in the Alps can be interpreted in the more general framework of the shrinking of the national level which made possible new scalar configurations (Swyngedouw 2004, 132) and alternative perimeters of cooperation (Häkli 2008, 475). In the Alps, one of the most interesting phenomena to take place since the 1990s is the establishment of networks of local political actors. The story starts in 1991, when the eight Alpine states signed an international treaty called the Alpine Convention. The European Union (EU) subsequently funded a six-year program (2007-2013) to promote transnational cooperation in the Alps in order to encourage the main principle of the convention, sustainable development.

These initiatives, identified by some scientists as "top-down" (Bätzing 1994), set a framework that enabled local, "bottom up" projects to gain importance. They often took the form of panAlpine networks, involving, among other elements, municipalities, cities, ski resorts, protected areas, and enterprises. Members of these networks are local political actors acting at a given common scale, in this case inside the Alpine Convention's limits, and transcending existing administrative national borders. While proposing a new mode of interaction, the network stemmed from those activities and institutions also fixed new territorial borders, the ones of the Alpine region as defined by the Alpine Convention. These processes, "from above" and "below", illustrate Paasi's $(2003,112)$ theoretical point when he suggests that it is exactly the combination of top-down and bottom-up processes that create territories.

These two different forms of modus operandi, vertical and horizontal, taking place in the Alps, are useful for understand the links between networks and territories. Networks, indeed, have an effect on geography. The issue is analyzed by the French geographer Fourny, in her research on the Alpine Town of the Year network. Fourny observed, by looking at the rhetoric of the network, 
that a shift in status of the territoire of reference had taken place. The Alpine Town of the Year network refers to the Alps in order to justify its common action and its role in the management of that space. Doing so, Fourny $(1999,179-180)$ says, the Alpine towns, connected via a network, contribute to politically build the Alpine territoire politically, to creating a public space, an object that will be collectively debated. As a result of the networks' activity, a process of redefinition of the territoires of actions, and so a redefinition of borders, is also taking place, in parallel to the renegotiation of collective identities. This can be seen in the activities of the EU's cooperation projects, such as INTERREG. In fact, as Bray (in Keating 2004, 12) admits, they "have helped to redefine borders as complex zones in which multiple identities can be expressed and negotiated" and where identities are performed into actions and projects.

While performing networked projects and actions, new types of horizontal cooperation that are no longer linked to old territorial units draw new geographies, as Leitner (Leitner in Marston et al. 2005, 417) argues: "transnational networks represent new modes of coordination and governance, a new politics of horizontal relations that also have a distinct spatiality". Or, as Bulkeley $(2005,888)$ underlines, networks' activities are not outside their boundaries, in "the ways in which they operate and the ways in which they are framed, configured and crystallized." If this is true, Allen and Cochrane (2007) would suggest that actors, in order to be able to govern these "transgressing entities," also need to somehow fix those new spaces of action. This creates a tension between the necessity to spread activities beyond given boundaries and the need to fix these same activities in order to govern them. This conception of territories and networks recalls Bulkeley's $(2005,888)$ dual observation that on the one hand scalar boundaries are fluid and contested, and, on the other, that networks are at the [p.37] same time, and contrary to what it is commonly thought, bounded. This recognition, so Bulkeley hopes, "may provide the basis for further constructive dialogue" between the two concepts $(2005,888)$.

The two notions of networks and territories seem to coexist in, as Bulkeley calls them, "new networked arenas" $(2005,897)$. These confirm that "geographical scales and networks of spatial connectivity can be seen as mutually constitutive rather than mutually exclusive aspects of social spatiality" (Bulkeley 2005, 888). Indeed, Bulkeley stresses the fact that "networks, scales and territories are not alternatives, but are intimately connected in both a politics of scale, and in creating new arenas of political authority and legitimacy" $(2005,896)$. She employs the example of how climate change is governed, but other examples could be used to illustrate this link between networks and territories. This brings us back to the idea of Elissalde $(2002,195)$, who argues that in some ways territories are networks, without, however, denying that fluid and unbounded spatial arrangements do not require "greater fixity and boundedness" (Murphy 2012, 170).

The concept of "scaled networks" proposed by Leitner, Sheppard, and Sziarto (2008a, 287; Leitner et al. 2008b, 162) seems suitable to address Burkeley's criticism about the dual vision of scales and networks. In the case of the Alps, the scale of the Alpine Convention is the reference used by local political actors, but their activities are anchored in networks connecting different points of the Alpine scale. Thus, it is useful to view the Alps as not a covering but rather a spanning geographical space (Leitner et al. 2008a, 287; Leitner et al. 2008b, 162), since it combines processes of scaling with processes of networking. It demonstrates that it is useful to think in terms of a co-construction of networks and territories. 


\section{Transgressing bounded spaces?}

The idea of considering networks and territories as co-constructed entities is possible only if territory is not necessarily conceived as state bounded, an idea that seemed unimaginable for Anglophone geographers, at least until the arrival of the idea of a relational territory and space, defended, among others, by Massey (2004, see Dell'Agnese 2013). Yet, territory can be considered in terms of bounded space, although not necessarily state bounded. In that case a question raised by Elden $(2010,12-13)$ remains unanswered: What is this (bounded) space and how are these boundaries possible? One can find two answers in the literature.

First, this space could be the unit of reference in a world imagined to be a patchwork formed by bi-dimensional, non-overlapping geometric forms, where every unit presents an internal integrity (or homogeneity) and a distinct identity (Painter 2009, 57; Painter 2010, 1091). This is not without analogy to observations made in animal societies, where territory is exclusive to members of the same species and is limited by a boundary (Bonnemaison 1981, 253). This is normally the vision of the world held by scholars who consider territory as a state prerogative, where territories are demarcated by clear boundaries (Painter 2010, 1094). So, the integrity of this space would be provided by sharing the same national space. This would be the vision favored by Anglophone geographers.

The second possibility better matches the Francophone understanding of territoire and could be seen as the area of daily practices and relations. In that case, geographical limits are defined by the surface where those take place (Raffestin in Bonnemaison 1981, 260). Francophone scholars share this view with other geographers stemming from the Anglo-Saxon tradition. Cox, for instance, does not consider territory to be limited only by jurisdictional boundaries. For him, its delimitation could be understood in a broader sense as "bounded zones" capable [p.38] of containing any social relations (Cox 1991, 5-6). Territory, in this sense, is the container of localized social and/or (non-invariably state) power relations (Cox 1991, 6; Agnew 1999, 503).

If both options are valid, especially taking into account the epistemological tradition into which they are inserted, nonetheless problems arise when they are considered simultaneously, as Jaillet $(2009,115)$ does by saying that "territoire designates at the same time a political circumscription and the group's living space." Yet, these two areas are not always spatially equivalent. It is for that reason that Anglophone geographers turned the back to territory and preferred "place" instead: exactly because territory was considered as a bounded space; this is, bounded by national borders (Antonsich 2009, 790). This is in fact one of the plausible reasons that Painter cites to explain the rationale for why Anglophone geographers, feeling some "embarrassment" with regard to territory, deciding to opt for other concepts (Painter 2010, 1091). Building from this point, Anglophone geographers distinguish the "sense of territory" from the "sense of place" by giving more importance to the second than to the first option:

"The sense of place literature places little emphasis on the specific boundedness of place. The sense of territory, however - at least as tied to regimes of territorial legitimation - is inextricably tied to the modern state system, and as such bears the imprint of the system's territorial logic" (Murphy 2002, 197-198).

\section{Territoire $=$ place?}

It was in the 1970s and 1980s that territoire gained importance in Francophone geography, which corresponded to the moment when the symbolic dimension of territoire started being 
essential in geography, when researchers began to think in terms of appropriation and "espace vécu" (lived space). It is from that moment onwards that Anglophone researchers converged on the concept of "place." Place, in the Anglo-Saxon world, gave geographers the possibility of introducing the social, cultural and political dimensions of space and provided a critique of political territory, of its rigid delimitation and of its state control (Debarbieux 1999, 42). This enabled Debarbieux $(1999,42)$ to say that the meanings given to the term "place" in Anglophone geography recall the innovations occurring in Francophone geography with territoire.

"Place" and "sense of places," thus helped Anglophone geographers to go beyond the "territorial trap," a term coined by Agnew to acknowledge geographical assumptions about states: particularly that these are fixed units of sovereignty, that there is a polarity between "domestic" and "foreign" policies, and that states are simply "containers of societies" (Agnew 1994). And, as Elden $(2010 a, 757)$ reminds his readers, the "trap" is not the territory itself, it is rather "certain ways of thinking about territory." And, as Elden (2010a, 760) regrets, the "territorial trap" has been avoided by simply not being mentioned in scientific texts instead of being critically interrogated. So, it is important to "highlight the mistaken assumption that the spatialities of state power and state territory are homomorphic" (Painter 2010, 1095). Analysis of territorial networks are one of these "escape routes from the "territorial trap"' identified by Bulkeley (2005, 881).

If, as discussed above, epistemologically, place in English has the same effect as territoire, in French, place is often translated into French by lieu, a concept that requires further explanation. The link between lieu and territoire in Francophone geography is well taken up in a paper by Debarbieux $(1995,14)$ devoted to this issue: "Metaphorically, the lieu symbolizes the territoire, but the lieu is as well a metonym, or, more exactly, a synecdoche, the whole, territoire, can be said by its parts, the lieu." Debarbieux's theory meets Di Méo's (1998, 110), [p.39] who argues that the difference between lieu and territoire is given by their scale and by their "geographical readability": territoire is abstract, ideal, lived, and felt more than visually detected and limited; territoire includes the lieux, which are defined, as opposed to territoires, by their striking reality due to their "valeur d'usage" (use value). Yet, Di Méo $(1998,108)$ continues, if lieux differ from territoire on those points, they converge in the fact that both are spaces qualified by society (or "semiotized", as Raffestin would say). Debarbieux (1995, 14-15) uncovers the link between lieu and territoire in a similar way, stating that

"A territory [un territoire] is a social construct that connects a material base made of a geographical space [un espace géographique] to a system of values that gives multiple and combined meanings to each component of this space (the places [lieux]), but also the spacing [espacements] and the discontinuities it encompasses."

Lieux as by Di Méo means them - that is, areas of daily practice - are considered to be relatively small: they are defined by the contiguity of the points and webs composing them, by the copresence of human beings and things which convey a spatial meaning (Di Méo 1998, 108). Lieux can be so dense with meaning that they connect at the same time two geographical scales: the one of the emplacement (location) and the one of the territoire to which they refer (Debarbieux $1995,14)$. Lieux, thus, are simultaneously not only fragments of the territoires, but also figures able to reveal their quintessence (Debarbieux 1995, 14). As conceived by Debarbieux and Di Méo, lieu thus entails an essential difference from "place": "Place [lieu], unlike territory [territoire] abolishes distance; while geographical territory abhors bordering [bornage], place draws its substance from it" (Di Méo 1998, 108). 


\section{Networked territories and territorial networks}

Thus, territory can be conceived as escaping boundaries in general and national boundaries in particular:

"Spatial practices, the ways in which space is produced and used, have changed profoundly. In particular, both territorial states and non-state actors now operate in a world in which state boundaries have become culturally and economically permeable to decisions and flows emanating from networks of power not captured by singularly territorial representations of space" (Agnew 1994, 72).

The most emblematic example underscoring this tendency is the over-used expression of "global" or "world economy," terms used to indicate that monetary flows are circulating worldwide without being stopped by any state border. Indubitably, these socio-political trends influence the ways in which social scientists in general and geographers in particular acknowledge the links between territories and networks, although these links are conceived in a different way in Anglophone and Francophone geography.

One of the main and most interesting Anglophone contributors to this debate is certainly Painter, who discussed this issue in two papers $(2009,2010)$, in which he defends the thesis that territory and network are not "as is often assumed, incommensurable and rival principles of spatial organization, but are intimately connected" (Painter 2010, 1093-1094). In Francophone geography, the possibility that networks and territories are connected, or highly integrated, has a longer heritage. Already in 1981, Bonnemaison $(1981,254)$ wrote [p.40] that "territoriality covers both what is fixed and what is mobile, in other words, itineraries as much as lieux." Three years later, Raffestin and Turco $(1984,45)$ affirmed almost the same idea with their definition of territoire as produced from space through the networks, circuits and flows projected by social groups. Elissalde $(2002,195)$ builds upon articles published in the 1980s to argue, 20 years later, that "a geography of territoires cannot be limited on the study of delimited or nested surfaces; territoires are networks," adding "... and not only for nomads" (that is, in Western societies as well). Elissalde $(2002,197)$ finds it as futile to oppose territoire and réseaux (networks) as it is to avoid imagining blurred boundaries and overlapping territories. This conception of territories, however, is only possible if they are considered beyond their jurisdictional meaning.

The Alpine case study shows the fruitfulness of this approach, since it pushes scholars to conceive territories not only as a mere "given spatial entities" fixed by administrative units, but as constructed and flexible portions of space. This conception, however, has been more deeply analyzed by Francophone than by Anglophone geographers. An exception is the Painter's article, in which he proposes to "rethink territory" by using a large number of Francophone sources long ignored by Anglophone scholars (Klauser 2012: 107). By doing so, he fills a gap that Fall (2007) attributes to the fact that, mostly for institutional reasons, the prosperous theorists of territoire, among them the Swiss geographer Raffestin, never dared to go beyond Francophone boundaries. But what is this "Francophone conception" of territories? The aim of what follows is to answer this question.

\section{The "Francophone" territoire versus the "Anglophone" territory}

Concerning territory, two different paths have been followed, two separate ways not profiting from possible mutual fertilization. As Chamussy $(2003,168)$ declared, "There still does not exist, for the moment, an English equivalent for the word territoire as it is understood by Francophone 
geographers." So, Painter's $(2010,1090)$ motto "territory is back" only makes sense in Anglophone geography, because in the Francophone tradition, territoire never disappeared. Painter, however, seems to be aware of his Anglo-centrism, when he writes that "until recently the concept of territory has not received the same level of attention, at least in the Anglophone literature" (Painter 2010, 1091); although territory was a key concept in an article he wrote together with Bialasiewicz and Elden (2005), in which they analyze it through the lens of the Treaty Establishing a Constitution for Europe. Thanks to this example, the three scholars found it useful to understand territory in a more "francophone way"; that is, going beyond his statecentric conception. They underline how territory is central to the process of European integration and how exactly European integration makes it possible to transcend "existing notions of territory, particularly those associated with the nation-state" (Bialasiewicz, Elden and Painter 2005, 335).

So, what do Francophone geographers mean by territoire? Historically, territoire broke into Francophone geography when cultural and symbolic dimensions were introduced in the concept following the growing interest for social and political geographers in concepts such as "power", "spatial control", "differentiation", "domination" and "social appropriation" (Alphandéry and Bergues 2004; Claval 1996, 96; Debarbieux 2003, 38). The emphasis on territoire corresponds to geography's claim to belong to social sciences and distance itself from a naturalist or mathematical conception of geography (Douillet 2003, 215). Territoire replaced the concept of région (region) first and espace (space) later (Chamussy 2003, 167; Debarbieux 2003, 36-37) and does not cleave to the idea that [p.41] territoire necessarily finishes where states do, as it is the case for the English "territory" (Debarbieux 2003, 35 and 42). The Anglophone perspective is well summarized in this statement: "Territory represents the extent of the sovereign power of the state" (Forsberg 2003, 13). The invitations of Sack (1983), Cox (1991) or Agnew (1999) to break with the necessity of analyzing power and control via the prism of the state have yet to come to fruition in the Anglophone study of territory.

\section{Tied between two poles: territoire, a specific notion or a buzzword?}

Giraut summarizes quite well this "richer" Francophone tradition, identifying two poles towards which the concept is tied: a specific notion, corresponding to the area of the (national) state, as for Anglophone geographers, and a buzzword, corresponding to a non-specified area (Giraut 2008, 59). These two tendencies are also distinguished by Alphandéry and Bergues (2004): a territory stemming from the maillage historique (traditional grid) on the one hand and, on the other, a territory taking different forms in space, which is produced and transformed by people and groups of people. The latter approach is a more diffused and less institutionalized way of conceiving territoire and it covers the idea that a territoire, insofar as it is such, has to be appropriated by individuals or groups of individuals. The appropriation can be concrete and/or symbolic (Bourdeau 1991, 30).

Giraut, in his analysis, put the idea of appropriation not as a possible shape that territory can take (maillage historique or space transformed by people as for Alphandéry and Bergues), but as the concept used by cultural geographers to analyze identities or by political geographers to signify power and control. Francophone geographers do not always conceive of power as necessarily linked to state power, since power is conceived as inherent to every social relation (Giraut 2008, 60; Tizon 1996, 27; Ozouf-Marignier 2009, 35).

"Appropriation" also played an important role in the debates between the partisans of espace 
(space) and the supporters of territoire. The first, espace, is primarily used by planners and technocrats who consider space as a donné (a "given thing"), something "flat," "uniform" and "without mystery" (Bonnemaison 1981, 260). The second, territoire, is privileged by geographers and is considered to be appropriated, invested with affect and subjectivity; it is vécu (lived) (Bonnemaison 1981, 260). In this sense territoire represents the socialization of espace (Bourdeau 1991, 29; Klauser 2012, 111). The role of humans and groups of humans is thus crucial in this movement from "space" to "territory", since territories are built by humans through technical actions and discursive practices (Claval 1996, 97). Raffestin usefully suggests that territorial arrangements constitute a "semiotization of space"; that is, a space, the material world, progressively transformed into territoire (Raffestin 1986a, 181; Raffestin 1986b, 94).

These conceptions are akin to the three orders of territoire suggested by Di Méo $(1998,108)$ : materiality; individual psyche (an emotional and presocial relation of human beings with the Earth); collective, social and cultural representations. Geographers rarely use the second order, but the other two can be frequently found in the literature, since geographers insist on the dual dimension, material and ideal, ecological and symbolic, of territoire (Debarbieux 1999, 36; Claval 1996, 97; Tizon 1996, 21; Elissalde 2002, 195). This is also the case for the three dimensions of territory distinguished by Hassner: material, symbolic and functional (Hassner in: Paasi 2003, 109). And the inclusion of immateriality and representation is exactly what distinguishes a territoire from a Euclidian space. [p.42]

\section{"Territory is what people make it to be"}

In social sciences territory is a useful tool for introducing the logics of agents (Ozouf-Marignier 2009, 34), since, as Knight suggests, it is "actions that give territory meaning" (Knight 1982, 517). This is also Paasi's main point $(2003,110)$ in his contribution to the first edition of this Companion, since he considers territories to be "social processes in which social space and social action are inseparable." This idea of "social action" allowed Francophone geographers, as Giraut $(2008,57)$ argues, to shift the focus from the state territory to a territory in the hands of individuals and multiple collectivities. Territory becomes the place where action and social thoughts are possible, while entering into contact with, transforming, and "deforming" (Di Méo 1991, 145) materiality (Barel in Marié 2004, 90). In that sense, what is interesting about territoire is that it opens up for geographers the possibility of inverting their emphasis from materiality to immateriality (or "semiosphere," using Raffestin's vocabulary); that is, from space to the instruments and codes of actors leaving traces in the territory (Raffestin 1986b, 94). It was through the awareness of the capacity of individuals and collectivities to model territories that a shift took place in Francophone geography: from a territory linked to its national referent to a territory of belongings, projects, and individual and collective practices (Giraut 2008, 57).

It was indeed when the idea of projet started circulating among geographers that territoire became a "fetish object", as Giraut describes it $(2008,61)$, not only for cultural and political geographers but also for economic geographers in France, who from the 1950s and until the "territorial turn" in the 1980s (Benko 2008, 38) preferred conceptualizations of space to those of territory, finding space more useful for their abstract and quantitative analysis of economic phenomena (Benko 2008). Yet, the economic crisis in the 1970 s and the subsequent idea that "development" cannot be stirred from above provided an opportunity to argue that the solution to the crisis would be to advocate for territorialized production and local development, often qualified as a "territorial development" (Giraut 2008, 61) and supported by local claims (Debarbieux 1999, 38). This is emblematically summarized in a sentence uttered by French 
Minister of planning in 1997 and reported by Benko $(2008,41)$ : "There are no territories in crisis, there are only territories without projects." Thus, economic geographers have been interested from that moment on in how specialized districts could boost the economy and in what manner territorial resources could be able to generate added value.

Cultural geographers instead stress the first aspect that Giraut distinguishes when he defines appropriation; that is, the symbolic dimension of territoire. Bonnemaison, for instance, argues that the symbolic relation between culture, which other scholars call "representations" (Tizon 1996, 21; Claval 1996, 102) or "imaginary" (Corboz 2001, 214; Tizon 1996, 21), and space, or materiality, is realized through the territoire (Bonnemaison 1981, 254). In that sense, territoire should be considered a material and symbolic mediator between a group and its culture (Bourdeau 1991, 41); it is a "savant mélange," a clever mix, of materiality and ideal (Tizon 1996, 21 ), in which identity plays an important role. Claval suggests that identities are built from the representations that transform some portions of the humanized space into territories (Claval 1996, 102). From a similar perspective, Bourdeau argues that territoires and shared cultures comprise the main components of collective identities: If territoire represents the spatial and temporal dimensions of identity, culture reflects the historical, mnemonic, and symbolic ones (Bourdeau 1991, 42). This leads Bourdeau to posit that territoire is at the same time the cultural mirror of an identity and the identity mirror of a culture (Bourdeau 1991, 42); a mirror keeping outside the Other, alterity (Piveteau 1995, 114). [p.43]

We thus come back to Giraut $(2008,59)$, who situates "identity" as the pivotal concept for cultural geographers to describe territorial "appropriation." However, for Bonnemaison and Cambrezy $(1996,13)$ for instance, territory is not stirred by a material but by a cultural principle of appropriation; that is, by "belonging." The idea of appropriation and belonging refers to the original use of territory - the translation of what ethologists observed in the animal realm into social realities. Taking advantage of considerations made in animal groups, social scientists were called to analyze the means that social subjects implement to control space (Claval 1996, 95). Yet, natural scientists consider territory to be an environment from which animals cannot escape, while human beings are able to thanks to culture and through a process of semiologization (Raffestin 1986c, 76). Following Tizon (1996, 34), human societies, compared to animal societies that define territories as spaces of exclusion, can modify their territories and transform them, following their aspirations, into places of social differentiation (or even segregation) or, on the contrary, into places of gathering and belonging. It is by gathering together that people can use the inherent potentialities of space and transform it into territoire, by implementing those potentialities into projects (Bourdeau 1991, 29). So, as Aase sums it up: "Territory is what people make it to be" (in Forsberg 2003, 10, see as well Dell'Agnese 2013, 118). This is, obviously, radically different from the Taylorian conception of territories and territoriality, considered as the "geographical link between states and nations" (Taylor 1995, 3).

\section{Conclusion}

The Alpine case suggests that, even today (or perhaps especially now), in an era in which states seem to be undermined (or at least reshaped) by transnational networks, there is interest in continuing to foster the concept of territory. Territories did not disappear; they are still "inescapable principles of social life" (Antonsich 2009, 801) and they still remain a central dimension to understand the ways in which "'living together' is produced, organized, contested and negotiated" (Antonsich 2009, 801). Our understanding of them should change and take into account the fact that "if territories are portions of relational space, and not portions of abstract 
homogenised spaces, the quality of their interactions is not an (inescapable) outcome of the essentialised characteristics of homogenised populations, but a consequence of the sum of interactions within, and among, individuals" (Dell'Agnese 2013, 122-123); or, I would add, among collectivities of individuals.

Bonnemaison is quite clear on that point when he writes:

"The increasing of mobility and the diminishing of the "Westphalian" function of territoire did not dispossess it from every meaning or necessity. In the contemporary world the need still subsists, although territoire takes different forms and responds to multiple functions" (Bonnemaison and Cambrezy 1996, 10).

In that sense, scholars are now called to analyze how ideologies are changing as territorial logics are challenged (Murphy 2002, 198) and to reinterrogate territory (Elden 2010, 20).

These are times of "territorial complexity" (Giraut and Antheaume 2005, 29), of the blooming of "new regions." In Europe at least, the number of what Deas and Lord (2006) call "unusual arrangements" - that is, territorial arrangements not linked to the territorial state - considerably increased. Following these two scholars, in Europe there are already 146 regions transcending territorially bounded entities. These need a framework that allows for their [p.44] conceptualization, as the entire EU integration processes needs it (Bialasiewicz, Elden and Painter 2005; Clark and Jones 2008). The Francophone territoire could turn out to be the right tool to enrich this framework and to give substance to the "more work on territory" that Elden (2010a) advocates. Thus, Anglophone (and other) geographers could build upon what French geographers call territoire and take advantage from new perspectives to frame together a new and fascinating theory of "territory." [p.45]

\section{Bibliography}

Agnew, John. 1994. "The Territorial Trap: The Geographical Assumptions of International Relations Theory." Review of International Political Economy 1 (1): 53-80. DOI:10.1080/09692299408434268.

Agnew, John. 1999. "Mapping Political Power Beyond State Boundaries: Territory, Identity, and Movement in World Politics." Millennium - Journal of International Studies 28 (3): 499-521. DOI:10.1177/03058298990280030701

Allen, John, Allan Cochrane. 2007. "Beyond the Territorial Fix: Regional Assemblages, Politics and Power." Regional Studies 41 (9): 1161-1175.

Alphandéry, Pierre, and Martine Bergues. 2004. "Territoires en questions: pratiques des lieux, usages d'un mot." Ethnologie française 1: 5-12.

Antonsich, Marco. 2009. "On Territory, the Nation-State and the Crisis of the Hyphen." Progress in Human Geography 33 (6) (December 1): 789-806. DOI:10.1177/0309132508104996.

Ardrey, Robert. 1966. The Territorial Imperative: A Personal Inquiry into the Animal Origins of Property and Nations. New York: Atheneum, New York.

Badie, Bertrand. 1996. "La fin des territoires westphaliens." Géographie et Cultures 20: 113-118.

Bätzing, Werner. 1994. "Die Alpenkonvention - Ein internationales Vertragswerk für eine nachhaltige Alpenentwicklung auf dem mühevollen Weg der politischen Realisierung." In Gefährdung und Schutz der Alpen, edited by Herbert Franz, 185-204. Wien: Österreichische Akademie der Wissenschaften.

Benko, Georges. 2008. "La géographie économique: un siècle d'histoire." Annales de géographie n 664 (6): 23-49. DOI:10.3917/ag.664.0023. 
Bialasiewicz, Luiza. 2012. "Off-Shoring and out-Sourcing the Borders of EUrope: Libya and EU Border-Work in the Mediterranean." Geopolitics 17 (4): 843-866.

Bialasiewicz, Luiza, Stuart Elden, and Joe Painter. 2005. "The Constitution of EU Territory." Comparative European Politics 3 (3): 333-63. DOI:10.1057/palgrave.cep.6110059.

Bonnemaison, Joël. 1981. "Voyage autour du territoire." Espace Géographique 10 (4): 249-262. DOI:10.3406/spgeo.1981.3673.

Bonnemaison, Joël, and Luc Cambrezy. 1996. "Le lien territorial entre frontières et identités." Géographie et Cultures 20: 7-18.

Bourdeau, Philippe. 1991. Guides de haute montagne: territoire et identité: recherches sur la territorialité d'un groupe professionnel. Grenoble: Revue de géographie alpine.

Bulkeley, Harriet. 2005. "Reconfiguring Environmental Governance: Towards a Politics of Scales and Networks." Political Geography 24 (8): 875-902.

Chamussy, Henry. 2003. "Le territoire, notion heuristique ou concept opératoire?" In Le territoire en sciences sociales: approches disciplinaires et pratiques de laboratoire, edited by Michel de Bernardy and Bernard Debarbieux, 167-182. Grenoble: Publications de la MSH-Alpes.

Clark, Julian, and Alun Jones. 2008. "The Spatialities of Europeanisation: Territory, Government and Power in 'EUrope.'” Transactions of the Institute of British Geographers 33 (3): 300318. DOI:10.1111/j.1475-5661.2008.00309.x.

Claval, Paul. 1996. "Le territoire dans la transition à la postmodernité." Géographie et Cultures 20: 93-112.

Corboz, André. 2001. Le territoire comme palimpseste et autres essais. Besançon: Ed. de L'Imprimeur.

Cox, Kevin R. 1991. "Redefining 'Territory."' Political Geography Quarterly 10 (1): 5-7. DOI:10.1016/0260-9827(91)90023-N.

Deas, lain, and Axel Lord. 2006. "From a New Regionalism to an Unusual Regionalism? The Emergence of Non-Standard Regional Spaces and Lessons for the Territorial Reorganization of the State." Urban Studies 43 (10): 1847-1877.

Debarbieux, Bernard. 1995. "Le lieu, fragment et symbole du territoire." Espaces et sociétés $n^{\circ} 80 \mathrm{~A}(1): 13-36$.

Debarbieux, Bernard. 1999. "Le territoire: histoires en deux langues. A Bilingual (his-)story of Territory." In Discours scientifiques et contextes culturels: géographies françaises et britanniques à l'épreuve postmoderne, edited by Christine Chivallon, Pascal Ragouet, and Michael Samers, 33-46. Bordeaux: Maison des sciences de l'homme d'Aquitaine.

Debarbieux, Bernard. 2003. "Le territoire en géographie et en géographie grenobloise." In Le territoire en sciences sociales: Approches disciplinaires et pratiques de laboratoire, edited by Michel de Bernardy and Bernard Debarbieux, 35-50. Grenoble: Publications de la MSHAlpes.

Del Biaggio, Cristina. 2013. "Linking up the Alps. How Networks of Local Political Actors Build the Alps". PhD Thesis, Geneva: University of Geneva.

Dell'Agnese, Elena. 2013. "The Political Challenge of Relational Territory." In Spatial Politics. Essays for Doreen Massey, edited by David Featherstone and Joe Painter, 115-132. Chichester, West Sussex ; Malden, MA: Wiley-Blackwell.s

Di Méo, Guy. 1991. L'homme, la société, l'espace. Paris: Ed. Economica.

Di Méo, Guy. 1998. "De L'espace aux territoires: éléments pour une archéologie des concepts fondamentaux de la géographie." L'information géographique 62 (3): 99-110. DOI:10.3406/ingeo.1998.2586.

Douillet, Anne-Cécile. 2003. "Le 'territoire' en science politique au regard des autres sciences sociales." In Le territoire en sciences sociales: Approches disciplinaires et pratiques de 
laboratoire, edited by Michel de Bernardy and Bernard Debarbieux, 207-225. Grenoble: Publications de la MSH-Alpes.

Elden, Stuart. 2010. "Land, Terrain, Territory." Progress in Human Geography (April 21). DOI:10.1177/0309132510362603.

Elden, Stuart. 2010a. " Thinking Territory Historically." Geopolitics 15 (4): 757-761.

Elissalde, Bernard. 2002. "Une géographie des territoires." L'information Géographique 66 (3): 193-205.

Fall, Juliet J. 2007. "Lost Geographers: Power Games and the Circulation of Ideas within Francophone Political Geographies." Progress in Human Geography 31 (2): 195-216. DOI:10.1177/0309132507075369.

Forsberg, Tuomas. 2003. "The Ground without Foundation: Territory as a Social Construct." Geopolitics 8 (2): 7-24. DOI:10.1080/714001038.

Fourny, Marie-Christine. 1999. "Affirmation identitaire et politiques territoriales des villes alpines." Revue de géographie alpine 87 (1): 171-180.

Giraut, Frédéric. 2008. "Conceptualiser le territoire." Historiens \& Géographes 403: 57-67.

Giraut, Frédéric, and Benoît Antheaume. 2005. "Au nom du développement, une (re)fabrication des territoires." In Le territoire est mort. Vive les territoires!, edited by Benoît Antheaume and Frédéric Giraut, 9-36. IRD Editions.

Gottmann, Jean. 1973. Significance of Territory. Charlotteville: University Press of Virginia.

Häkli, Jouni. 2008. "Re-Bordering Spaces." In Handbook of Political Geography, edited by Kevin Cox, Murray Low, and Jenny Robinson, 471-482. London: Sage.

Jaillet, Marie-Christine. 2009. "Contre le territoire, la 'bonne distance." In Territoires, territorialité, territorialisation. Controverses et perspectives, 115-121. Presses Universitaires de Rennes.

Keating, Michael. 2004. Regions and Regionalism in Europe. Edward Elgar.

Klauser, Francisco R. 2012. "Thinking through Territoriality: Introducing Claude Raffestin to Anglophone Sociospatial Theory." Environment and Planning D: Society and Space 30 (1): 106-20. DOI:10.1068/d20711.

Knight, David B. 1982. "Identity and Territory: Geographical Perspectives on Nationalism and Regionalism." Annals of the Association of American Geographers 72 (4): 514-531.

Leitner, Helga, Claire Pavlik, and Eric Sheppard. 2008. "Networks, Governance, and the Politics of Scale: Inter-Urban Networks and the European Union." In Geographies of Power: Placing Scale, edited by Andrew Herod and Melissa W. Wright, 274-303. Oxford: Blackwell Publishers Ltd.

Leitner, Helga, Eric Sheppard, and Kristin M. Sziarto. 2008. "The Spatialities of Contentious Politics." Transactions of the Institute of British Geographers 33 (2): 157-172. DOI:10.1111/j.1475-5661.2008.00293.x.

Marié, Michel. 2004. "L'anthropologue et ses territoires." Ethnologie française Vol. 34 (1): 89-96. DOI:10.3917/ethn.041.0089.

Marston, Sallie A., John Paul Jones, and Keith Woodward. 2005. "Human Geography without Scale." Transactions of the Institute of British Geographers 30 (4): 416-432.

Massey, Doreen. 2004. "Geographies of Responsibility," Geografiska Annaler 86 (1): 5-18.

Murphy, Alexander B. 2012. "Entente territorial: Sack and Raffestin on territoriality." Environment and Planning D: Society and Space 30 (1): 159-172.

Murphy, Alexander B. 2002. "National Claims to Territory in the Modern State System: Geographical Considerations." Geopolitics 7 (2): 193-214. DOI:10.1080/714000938.

Ozouf-Marignier, Marie-Vic. 2009. "Le territoire, la géographie et les sciences sociales: Aperçus historiques et épistémologiques." In Territoires, territorialité, territorialisation: 
Controverses et perspectives, edited by Martin Vanier, 31-35. Rennes: Presses Universitaires de Rennes.

Paasi, Anssi. 2003. "Territory." In A Companion to Political Geography, edited by John Agnew, Katharyne Mitchell and Gerard Toal, 109-122. Oxford: Blackwell.

Painter, Joe. 2009. "Territoire et réseau: Une fausse dichotomie?" In Territoires, territorialité, territorialisation. Controverses et perspectives, edited by Martin Vanier, 57-66. Presses Universitaires de Rennes.

Painter, Joe. 2010. "Rethinking Territory." Antipode 42 (5): 1090-1118. DOI:10.1111/j.14678330.2010.00795.x.

Piveteau, Jean-Luc. 1995. “Le territoire est-il un lieu de mémoire?” Espace Géographique 24 (2): 113-123. DOI:10.3406/spgeo.1995.3364.

Raffestin, Claude. 1986a. "Ecogenèse territoriale et territorialité." In Espaces, jeux et enjeux, edited by F. Auriac and R. Brunet, 173-185. Paris: Fayard. http://archiveouverte.unige.ch/vital/access/services/Download/unige:4419/FULLTEXT.

Raffestin, Claude. 1986b. "Territorialité: Concept ou paradigme de la géographie sociale?" Geographica Helvetica 41 (2): 91-96.

Raffestin, Claude. 1986c. "Punti di riferimento per una teoria della territorialità umana." In Esistere e abitare. Prospettive umanistiche nella geografia francofona, edited by Clara Copeta, 75-89. Milano: Franco Angeli. http://archiveouverte.unige.ch/vital/access/services/Download/unige:4421/FULLTEXT.

Raffestin, Claude, and Angelo Turco. 1984. "Espace et pouvoir." In Les concepts de la géographie humaine, 45-50. Paris: Masson. http://archive-ouverte.unige.ch/unige:4417.

Sack, Robert D. 1983. "Human Territoriality: A Theory." Annals of the Association of American Geographers 73 (1): 55-74. DOI:10.1111/j.1467-8306.1983.tb01396.x.

Soja, Edward. 1971. "The political organization of space." RP 8, Commission on College Geography, Association of American Geographers, Washington, DC, 1-54

Swyngedouw, Erik. 2004. "Scaled Geographies: Nature, Place, and the Politics of Scale." In Scale and Geographic Inquiry: Nature, Society, and Method, edited by Robert B. McMaster and Eric S. Sheppard, 129-151. London: Blackwell.

Taylor, Peter J. 1994. "The state as container: territoriality in the modern world-system." Progress in Human Geography 18 (2), 151-162. DOI: 10.1177/030913259401800202.

Taylor, Peter J. 1995. "Beyond containers: internationality, interstateness, interterritoriality." Progress in Human Geography 19 (2), 1-15. DOI: 10.1177/030913259501900101.

Tizon, Philippe. 1996. “Qu'est-ce que le territoire?" In Les territoires du quotidien, edited by Guy Di Méo, 17-34. Paris [etc.]: L'Harmattan.

\section{Biographical note}

Cristina Del Biaggio is a guest researcher at the Institute of European Studies, University of Amsterdam. She obtained her PhD at the University of Geneva in 2013. In her thesis she studied processes of regional institutionalization through a qualitative analysis of networks of local actors that took form from the 1990s in the Alps. Her current post-doctoral researchers relate to borders and migrations in Europe. 